\title{
Skredderens svulst
}

I dagens kasuistikker er pasienten anonymisert så godt det lar seg gjøre - som regel er det bare aldersgruppe og kjønn som oppgis. Tidligere oppga man i tillegg yrke, sivilstand, nøyaktig dato for innleggelsen og annet som eventuelt kunne være av interesse. Gitt den aktuelle gender-diskusjonen synger nå kanskje kjønn på siste verset? I en artikkel i Tidsskriftet nr. 21/1939 (her er kasuistikken tatt ut av anonymitetshensyn) redegjøres det for diagnostisering og behandling av glomustumor, en godartet svulst som kan være meget smertefull (Tidsskr Nor Lægeforen 1939; 59: 1125-8).

\section{Fra Møre og Romsdal Fylkessykehus. Chef: Dr. med. H. Fr. Harbitz.}

\section{Glomustumor.}

\section{Av H. Fr. Harbitz, Molde.}

En svulstart som visstnok er noget sjelden, men allikevel verd å kjenne til på grunn av sin smertefullhet, er den såkalte glomustumor. Jeg skal derfor referere et sådant tilfelle og kort omtale hvad som karakteriserer tumor. (...)

Denne tumoren har fått tallrike benevnelser, hvorav anglomyoneurom kan være verd å huske, da den angir tumors vevsbestanddeler.

Man mener disse glomustumores er fremgått av nogen små eiendommelige karelementer, arteriovenøse anastomoser, i hudens ytre lag. Disse såkalte glomi består av en tilførende liten arterie som deler sig i små trange kar, de såkalte Sucquet-Hoyer'ske kanaler, som atter samler sig i venene. Disse kar er endotelklædte og omgitt av tykke lag av epiteloide «glomusceller», hvis art og oprinnelse ikke er klarlagt. Dessuten finnes noget glatt muskulatur og et rikt nerveflettverk. Den hele kar- og celleansamling er omgitt av en fibrøs kapsel.

Disse glomi har en bygning som ligner glomus coccygeum.

Hudens glomi og deres svulster er fremfor alt studert av Masson og Popoff. De er ikke medfødte, men opstår først ca. en måned efter fødselen. De formodes å ha betydning for blodcirkulasjonen ved blodtrykks- og varmeregulering. Mangelen på glomi ved fødselen og deres sklerosering i høi alder kan muligens bidra til forklaringen av den vanskelige varmereguleringen hos nyfødte og eldre.

Den normale glomi forekommer fordelt med forskjellig hyppighet. Den er rikelig utbredt på ekstremitetene og fremfor alt i planta og palma og især under neglene. Der finnes ofte Vater Pacin'ske følelegemer i nærheten, og dette gir en viss formodning om relasjon mellem cirkulasjon og følelse.

Tumores i disse glomi, - hvis det er virkelige svulster og ikke bare hyperplasier - forekommer hyppigst hvor glomi er tallrikest på forhånd, altså på ekstremitetene, hyppigst på overekstremitetene og fremfor alt subungalt. Der er nettop som en eiendommelig lokalisasjon beskrevet to kasus med glomustumor på penis (Grauer og Burt). Hyppigst og mest karakteristisk er de små, meget ømfintlige, subunguale tumores. Størrelsen av glomustumores veksler fra under $1 / 2 \mathrm{~cm}$. til $2 \mathrm{~cm}$. i diameter. De kan i enkelte få tilfeller optre multipelt (Hval og Melsom). De sterke smerter synes vesentlig å forekomme når tumor utsettes for trykk og press, således under neglene, i palma og planta. Videre optrer paroksystiske smertekriser, og man kan også møte tilfelle med vasomotoriske forstyrrelser av hele den angjeldende ekstremitet uten at det lykkes å påvise direkte forbindelse mellem glomus og sympaticus. Sitter svulstene fritt i bløtdelene, kan de være smertefri.

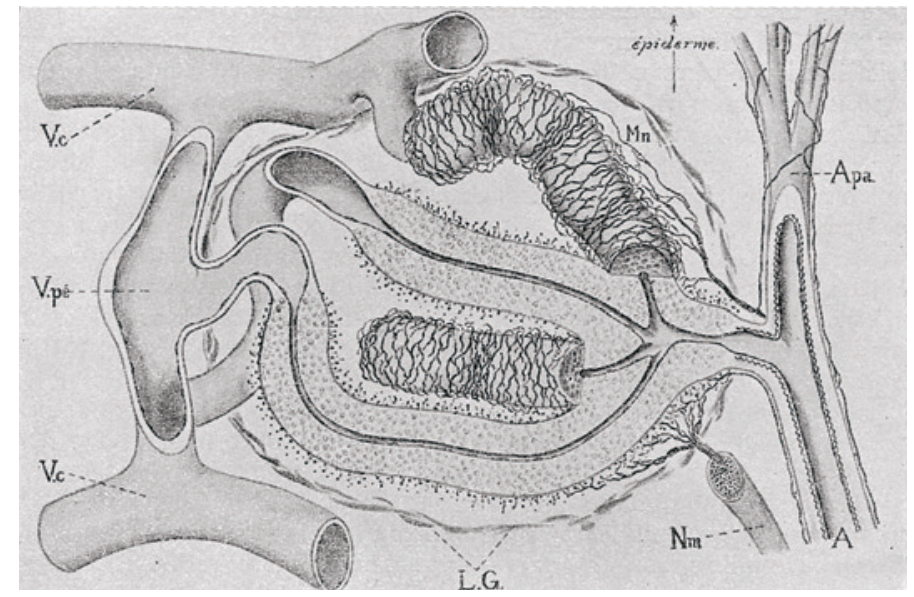

Massons skjematiske opfatning av en firedelt glomus. A-tilførende arterie deler sig i fire trange, snoete Sucquet Hoyer'ske kanaler som er omgitt av et tykt lag med særpregede epiteloide «glomusceller», som atter er omgitt av en nervefletning. De små karkanaler samler sig atter i venene, V.pe. Nm-nerve. L.G.-bindevevskapsel. (Masson, i det citerte arbeide, fig 5)

Av interesse er det at trauma finnes i anamnesen i omtrent halvparten av tilfellene. Det angis at tumor ofte består flere år før den gir symptomer.

Hvad behandlingen angår, er det bare radikal kirurgisk fjerning som helbreder. Eksstirpasjon er lett og recidiv opstår ikke. Strålebehandling, røntgen og radium, synes å være helt uten effekt. Dette har en viss interesse overfor de såkalte glomusceller som da sannsynligvis ikke kan være av angioblastisk karakter, da celler av den art i almindelighet reagerer godt på stråler.

Glomussvulstene er ennu referert $\mathrm{i}$ et forholdsvis beskjedent antall, antagelig bare ca. 100, så ethvert nytt tilfelle har interesse. Der eksisterer en ganske rikholdig litteratur. Interesserte vil jeg henvise til Hval og Melsom's oversikt i Medicinsk Revue, og Massons arbeider hvorav det nedenfor anførte gir en god oversikt.

Benyttet litteratur: Grauer og Burt. J. Am. Med. Ass. 112: 1806 1039. — Hval og Melsom: Med. Revue 1936 s. 545. - M. P. Masson: Les glomus cutanés de l'Homme. Bull d.i. Soc. Franç. d. Dermatol. et. d. Syphiligr. 1935 s. 1174 